\title{
Finansal Performansın Gri İlişkisel Analiz Yöntemi İle Değerlendirilmesi: Borsa İstanbul Ulaştırma Endeksi’ndeki Şirketler Üzerine Bir Araştırma*
}

Nazlı ERSOY *

\section{ÖZET}

Finansal performans değerlendirmesi, yoğun rekabet ortamında varlı̆̆ını devam ettirmek isteyen işletmeler için hassas ve dikkate alınması gereken önemli bir süreçtir. Bu tür bir değerlendirmede, kapsamlı ve etkin bir model geliştirmek için pek çok kriter ve alternatif ile karşı karşlya kalınmaktadır. Bu durum, Çok Kriterli Karar Verme (ÇKKV) problemi olarak görülmektedir. Bu çalışmada, Borsa İstanbul (BIST) Ulaştırma endeksinde (XULAS) işlem gören 8 firmanın finansal performansı Gri Iliş̧kisel Analiz (GİA) yöntemi kullanılarak ölçülmüşür. 2016-2018 döneminin temel alındı̆̆ çalışmada, on üç finansal oran çalışma kapsamına dâhil edilmiş ve ardından firmaların performans sıralama sonuçları belirlenmiştir. Çalışma sonucunda, GíA değerlerinin çok yüksek sapmalar göstermediği ve yüksek kârlılı̆̆a sahip işletmelerin üst sıralarda yer aldı̆̆ tespit edilmiştir. Ayrıca, ulaştırma sektöründe faaliyet gösteren firmaların2016-2017 yılı performans siralamalarının genel olarak benzerlik gösterdiği belirlenirken, bu durumun 2018 yılında farklılık gösterdiği görülmüştür.

Anahtar Kelimeler: Finansal Performans Analizi, Çok Kriterli Karar Verme, Gri İlişkisel Analiz Yöntemi JEL Sınıflandırması: G10, C61, M40.

Evaluation of Financial Performance with Grey Relational Analysis Method: A Research Study on Companies in Borsa Istanbul Transportation Index

\section{ABSTRACT}

Financial performance evaluation is a critical and important process to be taken into consideration for the enterprises that want to survive in an intense competitive environment. In such an evaluation, there are many criteria and alternatives for developing a comprehensive and effective model. This is seen as a multi-criteria decision making problem. In this study, the financial performance of 8 companies listed in Borsa Istanbul Transport Index (BIST) was measured by using Gray Relational Analysis (GRA) method.13 financial ratios were included in this study based on the 2016/2018 period, and then the performance ranking results of the companies were specified. As a result of the study, it was found that the GRA values did not show very high deviations, and high profitability enterprises were in the top rankings. Moreover, it was observed that the performance rankings of the companies operating in the transportation sector generally similar in 2016/2017 were different in 2018.

Keywords: Financial Performance Analysis, Multi Criteria Decision Making, Grey Relational Analysis Jel Classification: G10, C61, M40.

* Makale Gönderim Tarihi: 09.08.2019, Makale Kabul Tarihi: 21.10.2019, Makale Türü: Araştırma Makalesi

* Arş. Gör., Kilis 7 Aralık Üniversitesi, İktisadi ve İdari Bilimler Fakültesi, ersoynazli3@gmail.com, Orcid ID: 0000-0003-0011-2216. 


\section{GíRiş̧}

Ulaşım; tarım ve sanayi sektörleriyle yakın derece bağlantılı olması nedeniyle ülke ekonomisinin motoru konumundadır. Ekonomik, sosyal, siyasi, askeri, toplumsal ve çevre boyutları olan ulaştırma ise ekonomik kalkınmanın sağlanmasında kullanılabilen önemli bir araçtır (Erdoğan, 2016: 189). Ulaştırma, yatırım kararlarının alınmasında fayda-maliyet analizinin yapıldığı ilk alanlardan biridir. Ulaştırma sektörü; üretim sürecinin önemli bir parçasını oluşturması ve gerektirdiği önemli yatırımların ekonomide yarattığ 1 etkiler açısından toplumların ekonomik yapıları içinde ağırlıklı bir yere sahiptir (Gerçek, 2001: 90).

Ülkelerin ekonomik kalkınmasında önemli bir yere sahip olan ulaştırma sektöründe performans değerlendirmesinin yapılması ise o ülkelerdeki gelişimin takip edilmesi bakımından oldukça önemlidir. Ancak ulaştırma sektöründe performans ölçümünde birbiriyle çelişen çok sayıda kriter ve alternatifi dikkate almak gerekmektedir. Bu özelliğiyle, ulaştırma sektöründe performans ölçümü bir Çok Kriterli Karar Verme (ÇKKV) problemi olarak ele alınmaktadır.

Bir problemin ÇKKV problemi olarak görülebilmesi için en az 2 alternatif ve birbiriyle çelişen birden fazla kriterin olması gerekmektedir. Bu tarz problemleri çözebilmek için ise birbirinden farklı özelliklere sahip pek çok ÇKKV tekniği geliştirilmiştir. Az miktarda veri kullanarak tatmin edici sonuçlar üretebilen Gri İlişkisel Analiz (GİA), değerlendirme kriterlerine maksimum ve minimum yönlü değerlerin yanı sıra, karar verici tarafından belirlenen ideal değerlerin atanmasına imkân tanımakta ve bu yönüyle diğer ÇKKV yöntemlerinden ayrılmaktadır.

$\mathrm{Bu}$ çalışmada BIST'te işlem gören ve ulaştırma sektöründe faaliyet gösteren 8 firmanın finansal performansı ÇKKV tekniklerinden GİA yöntemiyle ölçülmüştür. Uygulamada, değerlendirme kriterlerine eşit ağırlık verilmiş, sonrasında ise bu ağırlıklar kullanılarak ilgili firmaların 2016-2018 dönem aralığı finansal performansı GİA yöntemiyle değerlendirilmiştir.

Çalışmanın diğer bölümleri aşağıdaki gibi organize edilmiştir. İkinci bölümde farklı sektörlerde farklı finansal oranlar ve farklı ÇKKV yöntemleri kullanılarak daha önce yapılmış performans ölçüm çalışmalarının özetlendiği bir literatür incelemesi yer almaktadır. Üçüncü bölümde, çalışmanın amacına, kapsamına ve kullanılan verilere yer verilmiştir. Dördüncü bölümde çalışma kapsamında kullanılan yöntemin matematiksel notasyon ve açıklamasına yer verilirken, beşinci bölümde çalışmanın uygulama kısmına yer verilmiştir. Son bölümde ise çalışmaya ilişkin genel bir değerlendirme yapılmış ve gelecek çalışmalara ilişkin önerilerde bulunulmuştur.

\section{LITERATÜR TARAMASI}

Uluslararası ve ulusal literatürde finansal performans analizinin ÇKKV yöntemleri kullanılarak yapıldığ 1 pek çok çalışmaya rastlamak mümkündür. Yapılan çalışmalarda farklı sektörler ve farklı finansal oranlar temel alınarak, farklı ÇKKV yöntemleriyle firmaların finansal performansları değerlendirilmeye çalışılmıştır. Finansal performansın ÇKKV yöntemleri ile ölçüldüğü uluslar arası ve ulusal alanda yapılan bazı çalışmalardan oluşan literatür taraması Tablo 1'de sunulmuştur. 
Tablo 1. Literatür Taraması

\begin{tabular}{|c|c|c|c|c|}
\hline Yazar/(lar) & Yöntem & Sektör & Kullanılan Finansal Oranlar & Sonuç \\
\hline (Wangvd.,2010) & TOPSIS & $\begin{array}{l}\text { Gayrimenkul } \\
\text { Sektörü }\end{array}$ & $\begin{array}{l}\text { Varlık Karlılığı Oranı, Sermaye Karlılığı } \\
\text { Oranı, Cari Oran, Hisse Başına Getiri } \\
\text { Oranı, Net Kâr Marjı Oranı, Stok Devir } \\
\text { Hızı Oranı }\end{array}$ & $\begin{array}{l}\text { Vietnam borsasında işlem gören ve } \\
\text { gayrimenkul sektöründe faaliyet gösteren } 13 \\
\text { firmanın finansal performanslarının } \\
\text { değerlendirildiği çalışmada, en yüksek önem } \\
\text { derecesine sahip olan finansal oranın aktif } \\
\text { kârlılığ } 1 \text { oranı olduğu tespit edilmiştir. } \\
\text { Önerilen modelin finansal performans ölçümü } \\
\text { için uygun olduğu tespit edilmiştir. }\end{array}$ \\
\hline $\begin{array}{c}\text { (Bo ve Haidong, } \\
\text { 2008) }\end{array}$ & TOPSIS & İmalat Sektörü & $\begin{array}{l}\text { Cari Oran, Likidite Oranı, Borçlanma } \\
\text { Oranı, Çalışma Sermayesi Oranı, } \\
\text { ÖzSermaye Kârlılığı Oranı, Aktif Kârlılığı } \\
\text { Oranı, Alacak Devir Hızı Oranı, Stok Devir } \\
\text { Hızı Oranı, Aktif Devir Hızı Oranı, Nakit } \\
\text { Akış/Cari Yükümlülükler Oranı, Hisse } \\
\text { Başına Kazanç Oranı }\end{array}$ & $\begin{array}{l}\text { İmalat sektöründe faaliyet gösteren } 112 \\
\text { firmanın analize dâhil edildiği çalışmada, } \\
\text { TOPSIS yönteminin tanınma oranının \%98,2 } \\
\text { seviyelerinde olduğu tespit edilmiştir. Bunun } \\
\text { yanı sıra, kullanılan finansal oranların, } \\
\text { kriterlere atanan değerlerin ve kullanılan } \\
\text { yöntemlerin analiz sonucuna etki edeceği } \\
\text { belirlenmiştir. }\end{array}$ \\
\hline $\begin{array}{c}\text { (Feng ve Wang, } \\
\text { 2000) }\end{array}$ & $\begin{array}{l}\text { GİA, } \\
\text { TOPSIS }\end{array}$ & Havayolu Sektörü & $\begin{array}{lll}\text { Cari Oran, ÖzSermaye } & \text { Oranı, } \\
\text { ÖzSermaye/Duran Varlık Oranı, Duran } \\
\text { Varlık/Uzun Vadeli Yabancı Kaynak Oranı, } \\
\text { Kaldıraç Oranı,ÖzSermaye/Borç Oranı, İşş } \\
\text { Gücü, Filo, Uçuş Ekipmanları ve Varlık } \\
\text { Verimliliği ile İlgili Oranlar }\end{array}$ & $\begin{array}{l}\text { Havayolu sektöründe faaliyet gösteren } 5 \\
\text { firmanın analiz kapsamına dâhil edildiği } \\
\text { çalışmada, finansal oranlar kullanılarak } \\
\text { yapılan performans değerlendirmesinin daha } \\
\text { kapsamlı sonuçlara ulaştırdığı tespit edilmiştir. }\end{array}$ \\
\hline (Shaverdivd., 2014) & $\begin{array}{c}\text { FUZZY } \\
\text { AHP }\end{array}$ & Petrokimya Sektörü & $\begin{array}{l}\text { Cari Oran, Likidite Oranı, Kaldıraç Oranı, } \\
\text { Uzun Vadeli Yabancı Kaynak/ÖzSermaye } \\
\text { Oranı, Uzun Vadeli Yabancı } \\
\text { Kaynak/Toplam Varlı Oranı, Faiz } \\
\text { Karşılama Oranı, Net Kâr Marjı Oranı, } \\
\text { Aktif Karlılığı Oranı, ÖzSermaye Karlılığı } \\
\text { Oranı, Varlık Büyüme Oranı, Satış Büyüme } \\
\text { Oranı, Faaliyet Kârı Büyüme Oranı, } \\
\text { ÖzSermaye Büyüme Oranı, Sabit Aktif } \\
\text { Devir Hızı Oranı, Envanter Dönüşüm Hızı }\end{array}$ & $\begin{array}{l}\text { Petrokimya sektöründe faaliyet gösteren } 7 \\
\text { firmanın finansal performansının Fuzzy AHP } \\
\text { yöntemi ile değerlendirildiği çalışma sonunda, } \\
\text { önerilen yöntem ile başarılı sonuçlara varıldığ } \\
\text { tespit edilmiştir. }\end{array}$ \\
\hline
\end{tabular}




\begin{tabular}{|c|c|c|c|c|}
\hline & & & $\begin{array}{l}\text { Oranı, Aktif Devir Hızı Oranı, Alacak } \\
\text { Devir HızıOranı }\end{array}$ & \\
\hline (Wang, 2008) & $\begin{array}{l}\text { GİA, } \\
\text { FUZZY } \\
\text { TOPSIS }\end{array}$ & Havayolu Sektörü & $\begin{array}{l}\text { Cari Oran, Likidite Oranı, Nakit Oran, } \\
\text { Çalışma Sermayesi/Dönen Varlıklar Oranı, } \\
\text { Sabit Aktif Devir Hızı Oranı, Aktif Devir } \\
\text { Hızı Oranı, Brüt Kâr Marjı Oranı, Faaliyet } \\
\text { Kâr Marjı Oranı, Vergi Öncesi Kâr Oranı, } \\
\text { Net Kâr Marjı Oranı, Aktif Kârlılık Oranı, } \\
\text { ÖzSermaye/Toplam Borç Oranı, Kaldıraç } \\
\text { Oranı, Çalış̧a Sermayesi/Toplam Varlık } \\
\text { Oranı, Duran Varlık/Öz Sermaye Oranı, } \\
\text { Duran Varlık/ Uzun Vadeli Yabancı } \\
\text { Kaynak Oranı, Duran Varlıklar/Uzun } \\
\text { Dönemli Sermaye Oranı, Para Dolaşım } \\
\text { Hızı Oranı, Borç Devir HızıOranı, Alacak } \\
\text { Devir Hızıranı, Duran Varlık Devir } \\
\text { HızıOranı, Dönüşüm Oranı }\end{array}$ & $\begin{array}{l}\text { Tayvan'da havayolu sektöründe faaliyet } \\
\text { gösteren üç firmanın finansal performansını } \\
\text { değerlendirildiği çalışma sonucunda, önerilen } \\
\text { modelin finansal performans } \\
\text { karşılaştırmasında rahatlıkla kullanılabileceği } \\
\text { tespit edilmiştir. }\end{array}$ \\
\hline $\begin{array}{l}\text { (Moghimi ve } \\
\text { Anvari, 2014) }\end{array}$ & $\begin{array}{l}\text { FUZZY } \\
\text { AHP, } \\
\text { TOPSIS }\end{array}$ & Çimento Sektörü & $\begin{array}{l}\text { Cari Oran, Likidite Oranı, Kaldıraç Oranı, } \\
\text { ÖzSermaye/Toplam Varlık Oranı,Duran } \\
\text { Varlık/ÖzSermayeOranı,Duran Varlık/ } \\
\text { Uzun Vadeli Yabancı KaynakOranı, Alacak } \\
\text { Devir HızıOranı, Envanter Dönüşüm Oranı, } \\
\text { Dönen Varlık Devir HızıOranı, Aktif Devir } \\
\text { Hızıranı, Net Kar Marjıranı, } \\
\text { ÖzSermayeKârlılığıranı, Satış Büyüme } \\
\text { Oranı, Faaliyet KârıOranı, ÖzSermaye } \\
\text { Büyüme Oranı, VarlıkBüyüme Oranı }\end{array}$ & $\begin{array}{l}\text { Kriter ağırlıklarının sıralama sonuçlar } \\
\text { üzerinde önemli bir etkisi olduğu tespit } \\
\text { edilirken, önerilen modelin çimento } \\
\text { sektörünün yanı sıra diğer sektörlerde do } \\
\text { başarıyla uygulanabileceği vurgulanmıştır. }\end{array}$ \\
\hline $\begin{array}{l}\text { (Baležentisvd., } \\
\text { 2012) }\end{array}$ & $\begin{array}{c}\text { VIKOR, } \\
\text { TOPSIS } \\
\text { ARAS }\end{array}$ & İmalat Sektörü & $\begin{array}{l}\text { Brüt Kâr MarjıOranı, Aktif Kârlılığı } \\
\text { Oranı,KaldıraçOranı,Cari Oran, Alacak } \\
\text { Devir HızıOranı, ÖzSermayeDevir Hızı }\end{array}$ & $\begin{array}{l}2007-2010 \text { döneminin temel alındığ } \\
\text { çalışmada, en yüksek performans sergileyen } \\
\text { sektör ormanc1lı ve tomruk olarak } \\
\text { belirlenirken,ulaştırma sektörü ise ekonomik }\end{array}$ \\
\hline
\end{tabular}




\begin{tabular}{|c|c|c|c|c|}
\hline & & & Oran1 & kriz döneminin kurbanı olarak belirlenmiştir. \\
\hline (Farrokhvd., 2016) & $\begin{array}{l}\text { FUZZY } \\
\text { AHP, } \\
\text { TOPSIS } \\
\text { VIKOR }\end{array}$ & Metal Sektörü & $\begin{array}{l}\text { Cari Oran, Likidite Oranı,Kaldıraç Oranı, } \\
\text { ÖzSermaye/Toplam Varlı Oranı,Duran } \\
\text { Varlı/ö̈ZSermayeOranı,Duran Varlık/ } \\
\text { Uzun Vadeli Yabancı KaynakOranı, Net } \\
\text { Kâr MarjıOranı, } \\
\text { ÖzSermayeKârlıllığıOranı,SatışBüyüme } \\
\text { Oranı, Faaliyet KârıBüyüme Oranı, } \\
\text { ÖzSermaye ve Aktif Büyüme Oranları }\end{array}$ & $\begin{array}{l}\text { İran metal sektöründe faaliyet gösteren } 8 \\
\text { firmanın finansal performanslarının } \\
\text { değerlendirildiği çalışmada, kullanılan } \\
\text { VIKOR ve TOPSIS yöntemleriyle ulaşılan } \\
\text { sonuçların benzer olduğu tespit edilmiştir. }\end{array}$ \\
\hline (Esbouei vd., 2014) & $\begin{array}{l}\text { FUZZY } \\
\text { ANP, } \\
\text { FUZZY } \\
\text { VIKOR }\end{array}$ & İmalat Sektörü & $\begin{array}{l}\text { Aktif } \text { Kârlılı̆̆ıranı, } \\
\text { ÖzSermayeKârl1lığıOranı, Faaliyet Kârı } \\
\text { Büyüme Oranı, Fiyat-Kazanç Oranı, Katma } \\
\text { Değer, Piyasa Değeri, Ekonomik Katma } \\
\text { Değer, Katma Değer, Nakit Katma Değer, } \\
\text { Hissedar Değeri, TobinQOranı }\end{array}$ & $\begin{array}{l}\text { Tahran borsasında işlem gören } 143 \text { İran } \\
\text { firmasının finansal performans ölçümünün } \\
\text { gerçekleştirildiği çalış̧ada, en yüksek önem } \\
\text { derecesine sahip finansal oran faaliyet kâr } \\
\text { marjı olarak belirlenirken, firmanın daha } \\
\text { yüksek bir performans sergileyebilmesi için } \\
\text { ekonomik katma değer, piyasa katma değer } \\
\text { gibi ekonomik değer ölçülerine önem vermesi } \\
\text { gerektiği vurgulanmıştır. }\end{array}$ \\
\hline (Rezaievd., 2014) & $\begin{array}{l}\text { FUZZY } \\
\text { AHP, } \\
\text { VIKOR }\end{array}$ & Çimento Sektörü & $\begin{array}{l}\text { Cari Oran, Likidite Oranı, Nakit } \\
\text { Oran,KaldıraçOranı,ÖzSermaye/Toplam } \\
\text { Varlık } \\
\text { Varlık/ÖzSermayeOranı, Duran Varlık/ } \\
\text { Uzun Vadeli Yabancı KaynakOranı, Net } \\
\text { Kâr rarjıranı, } \\
\text { ÖzSermayeKârlılığıOranı,Satı̧B̈̈̈yüme } \\
\text { Oranı, Fäliyet } \\
\text { KârıBüyümeOranı,ÖzSermaye Büyüme } \\
\text { Oranı,Varlık Büyüme Oranları }\end{array}$ & $\begin{array}{l}\text { 2008-2009 dönem aralığının temel alındığ } 1 \\
\text { çalışmada en yüksek performansa sahp } \\
\text { firmaların yıllara göre farklıı gösterdiği } \\
\text { tespit edilmiş,çalış̧ada kullanılan bulanık } \\
\text { ÇKKV tekniklerinin finansal performans } \\
\text { ölçümünde rahatlıkla kullanılabileceği } \\
\text { sonucuna ulaşılmıştır. }\end{array}$ \\
\hline (Yalcinvd., 2012) & $\begin{array}{l}\text { FUZZY } \\
\text { AHP, }\end{array}$ & İmalat Sektörü & $\begin{array}{l}\text { Aktif Karlılı̆̆ı Oranı, Öz Sermaye Karlılı̆ı } \\
\text { Oranı, Hisse Baş1 Kazanç Oranı, Fiyat- }\end{array}$ & $\begin{array}{l}\text { Kriter ağırlıklarının Fuzzy AHP yöntemi ile } \\
\text { belirlendiği, } \quad \text { performans } \\
\text { siralamasının }\end{array}$ \\
\hline
\end{tabular}




\begin{tabular}{|c|c|c|c|c|}
\hline & $\begin{array}{l}\text { VIKOR, } \\
\text { TOPSIS }\end{array}$ & & $\begin{array}{l}\text { Kazanç Oranı, } \quad \text { Fiyat/Defter Değeri, } \\
\text { Ekonomik Katma } \\
\text { Değeger, Piyasa } \\
\text { Datma, Yatırım Getiri Oranı, Katma Değer } \\
\text { Oranı }\end{array}$ & 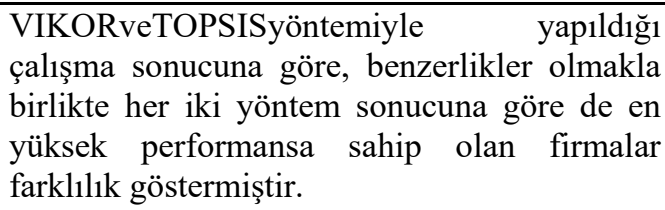 \\
\hline (Atmaca, 2012) & TOPSIS & Spor Sektörü & $\begin{array}{l}\text { Cari Oran, Nakit Oran, Aktif Karlılığı } \\
\text { Oranı, Net Kâr Marjı Oranı, Öz Kaynak } \\
\text { Karlılığı Oranı, Aktif Devir Hızı Oranı, Öz } \\
\text { Kaynak Devir Hızı Oranı, Net Çalışma } \\
\text { Sermayesi Devir Hızı Oranı, Borçlanma } \\
\text { Oranı, Yatı̈ım Oranı, Borçlanma Katsayısı } \\
\text { Oranı, Dönen Varlık/ Toplam Aktif Oranı, } \\
\text { Duran Varlık/ Aktif Toplamı Oranı, Kısa } \\
\text { Vadeli Yabancı Kaynak/Pasif Toplamı } \\
\text { Oranı, Uzun Vadeli Yabancı Kaynak/ Pasif } \\
\text { Toplamı Oranı, Öz Kaynak/Pasif Toplamı } \\
\text { Oranı }\end{array}$ & $\begin{array}{l}\text { Çalışma kapsamına alınan şirketlerin sportif } \\
\text { başarılarının veya başarısızlıklarının finansal } \\
\text { performans düzeylerinde önemli rol oynadığı } \\
\text { tespit edilirken, bu durumun şirketlerin } \\
\text { finansal tablolarına da yansıdığı görülmüştür. }\end{array}$ \\
\hline $\begin{array}{l}\text { (Ertuğrul ve } \\
\text { Karakaşoğlu, 2009) }\end{array}$ & $\begin{array}{l}\text { FUZZY } \\
\text { AHP, } \\
\text { TOPSIS }\end{array}$ & Çimento Sektörü & $\begin{array}{l}\text { Cari Oran, Asit Test Oranı, Nakit Oran, } \\
\text { Kaldıraç Oranı, ÖzKaynak/Toplam } \\
\text { VarlıkOranı, Duran Varlık/ÖzkaynakOranı, } \\
\text { Duran Varlık/ Uzun Vadeli Yabancı } \\
\text { KaynakOranı, Alacak Oranı, Envanter } \\
\text { Dönüşüm Oranı, Dönen Varlık Dönüşüm } \\
\text { Oranı, Toplam Varlık Dönüşüm Oranı, } \\
\text { Borç Devir Hızı Oranı, Net Kâr } \\
\text { MarjıOranı, Özsermaye Karlılık Oranı, } \\
\text { Satı̧̧ Büyüme Oranı, Faaliyet Kârı Büyüme } \\
\text { Oranı,Özsermaye Büyüme Oranı,Varlık } \\
\text { Büyüme Oranı, }\end{array}$ & 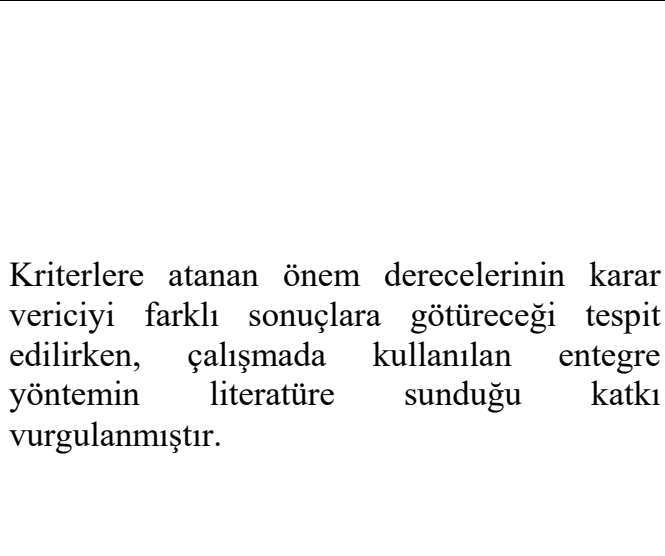 \\
\hline $\begin{array}{l}\text { (Kendirli ve Kaya, } \\
\text { 2016) }\end{array}$ & TOPSIS & Ulaştırma Sektörü & $\begin{array}{l}\text { Cari Oran, Asit Test Oranı, Nakit Oran, Net } \\
\text { İşletme Sermayesi/Toplam Aktif Oranı, } \\
\text { Borç Oranı, Kaldıraç Oranı, Kısa Vadeli }\end{array}$ & 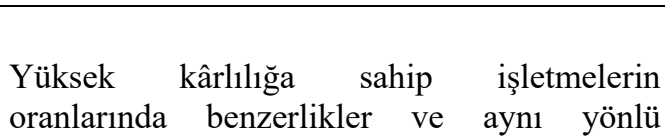 \\
\hline
\end{tabular}




\begin{tabular}{|c|c|c|c|c|}
\hline & & & 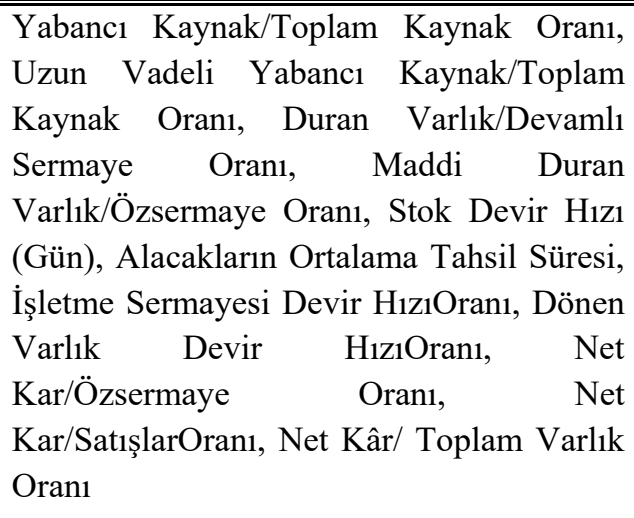 & $\begin{array}{l}\text { hareketler tespit edilirken, mali performansları } \\
\text { olumlu olan işletmelerin BIST'te de güvenilir } \\
\text { ve kazançlı işletmeler arasında olduğu tespit } \\
\text { edilmiştir.TOPSISyöntemiyle ulaşılan } \\
\text { sonuçların oran analizi yöntemiyle elde edilen } \\
\text { sonuçlarla tutarlı olduğu tespit edilmiştir. }\end{array}$ \\
\hline $\begin{array}{c}\text { (Akgün ve Temur, } \\
\text { 2016) }\end{array}$ & TOPSIS & Ulaştırma Sektörü & 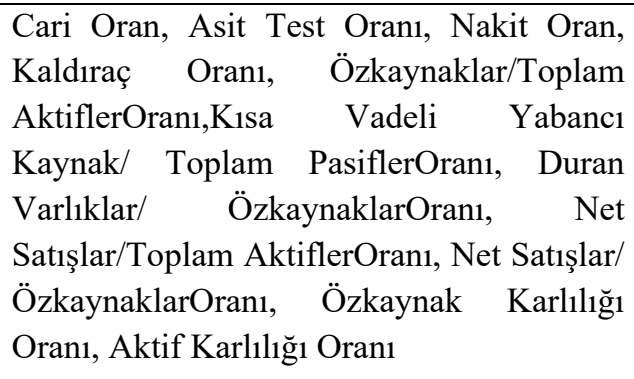 & 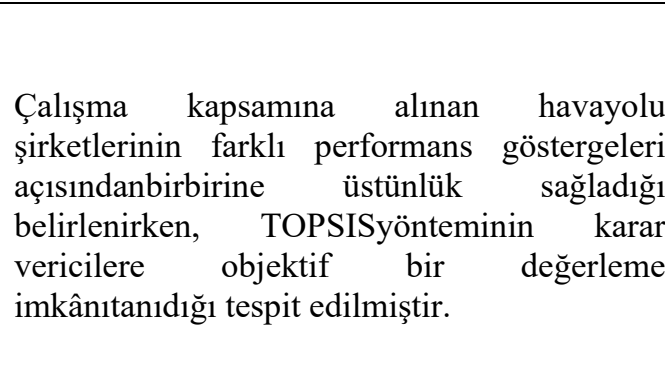 \\
\hline $\begin{array}{l}\text { (Ömürbek ve } \\
\text { Kınay, 2013) }\end{array}$ & TOPSIS & Ulaştırma Sektörü & $\begin{array}{l}\text { Cari Oran, Asit Test Oranı, Nakit Oran, } \\
\text { Faaliyet KârlılığıOranı, Net Kârlılık Oranı, } \\
\text { Kaldıraç Oranı, ÖzkaynakKârlılı̆ı̆Oranı, } \\
\text { Yolcu Doluluk Oranı }\end{array}$ & $\begin{array}{l}\text { Borsa İstanbul ve Frankfurt menkul kuymetler } \\
\text { borsasında işlem gören } 2 \text { farklı havayolu } \\
\text { firmasının finansal performanslarının } \\
\text { değerlendirildiği çalısmada, BIST’te işlem } \\
\text { gören firmanın daha yüksek performans } \\
\text { sergilediği tespit edilmiştir. }\end{array}$ \\
\hline $\begin{array}{c}\text { (Gümüş ve Çıbık, } \\
2019 \text { ) }\end{array}$ & $\begin{array}{l}\text { MOORA } \\
\text {, VIKOR }\end{array}$ & Ulaştırma Sektörü & 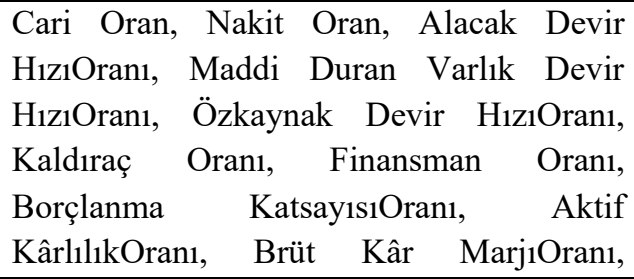 & $\begin{array}{l}\text { Uygulanan MOORA ve VIKOR yöntemleri } \\
\text { sıralama sonuçlarının yıllar itibariyle } \\
\text { benzerlik gösterdiği tespit edilmiştir. 2016- } \\
2017 \text { döneminin dâhil edildiği çalısmada, her } \\
\text { iki yılda da finansal performans bakımından } \\
\text { ilk sırada yer alan şirket aynı olmuştur. }\end{array}$ \\
\hline
\end{tabular}




\begin{tabular}{|c|c|c|c|c|}
\hline & & & Faaliyet Kâr MarjıOranı & \\
\hline $\begin{array}{c}\text { (Özdağoğluvd., } \\
\text { 2017) }\end{array}$ & GİA & İmalat Sektörü & $\begin{array}{l}\text { Cari Oran, Asit Test Oranı, Kaldıraç } \\
\text { Oranı,KârMarjıOranı, } \\
\text { ÖzSermayeKârlılığıOranı,EkonomikRantab } \\
\text { ilite,Brüt Kâr MarjıOranı,Faaliyet Kâr } \\
\text { MarjıOranı,Net Kâr MarjıOranı, Envanter } \\
\text { Dönüşüm Oranı, Olağan Gelir Oranı }\end{array}$ & $\begin{array}{l}\text { İmalat sektöründe faaliyet gösteren } 98 \\
\text { firmanın analiz kapsamına dâhil edildiğ } \\
\text { çalışmada, bir kırtasiye firmasının en yüksek } \\
\text { performansa sahip olduğu belirlenirken, } \\
\text { yüksek performansa sahip firmaların büyük } \\
\text { bir çoğunluğunun çimento ve gübre firmalar } \\
\text { içinde yer aldığ belirlenmiştir. İmalat } \\
\text { sektöründeki bütün firmaların analize dâhil } \\
\text { edilmesi nedeniyle de çalışmanın literatüre } \\
\text { önemli bir katkı yaptığı sonucuna varılmıştır. }\end{array}$ \\
\hline (Tayyar vd.,2014) & $\begin{array}{l}\text { AHP, } \\
\text { GİA }\end{array}$ & Bilişim ve Teknoloji & $\begin{array}{l}\text { Cari Oran, Asit Test Oranı, Nakit Oran, } \\
\text { Borç Oranı, Toplam Borç/Özsermaye } \\
\text { Oranı, Kısa Vadeli Yabancı } \\
\text { Kaynak/Toplam Aktif Oranı, Alacak Devir } \\
\text { Hızı Oranı, Özsermaye Devir Hızı Oranı, } \\
\text { Net Çalışma Sermayesi Devir Hızı Oranı, } \\
\text { Net Kâr MarjıOranı, Aktif Kârlılık Oranı, } \\
\text { Özsermaye Kârlılık Oranı }\end{array}$ & $\begin{array}{l}\text { En yüksek ağırlığa sahip kriterlerin kârlılık } \\
\text { oranları grubunda olduğu tespit edilirken, } \\
\text { uygulanan yöntemin söz konusu işletmelerin } \\
\text { finansal performanslarını sıralamada yeterli } \\
\text { olduğu belirlenmiştir. }\end{array}$ \\
\hline $\begin{array}{l}\text { (Dumanoğlu ve } \\
\text { Ergül, 2010) }\end{array}$ & TOPSIS & Teknoloji Sektörü & $\begin{array}{l}\text { Borçlanma Oranı, Kaldıraç Oranı, Dönen } \\
\text { Varlık Devir HızıOranı, Duran Varlık } \\
\text { Devir HızıOranı, Net Kâr MarjıOranı, } \\
\text { ÖzsermayeKârlılığıOranı, Cari Oran, Asit } \\
\text { Test Oranı }\end{array}$ & $\begin{array}{l}\text { Teknoloji şirketlerinin } \\
\text { performanslarına ilişkin analiz sonuçları, } \\
\text { temel analiz sonuçlarını doğrular nitelikte } \\
\text { çıkmıştır ve çalışmada kullanılan TOPSIS } \\
\text { yönteminin başarılı sonuçlara ulaştırdığı tespit } \\
\text { edilmiştir. }\end{array}$ \\
\hline $\begin{array}{c}\text { (Akbulut ve } \\
\text { Rençber, 2015) }\end{array}$ & TOPSIS & İmalat Sektörü & $\begin{array}{l}\text { Cari Oran, Asit Test Oranı, Nakit Oranı, } \\
\text { Alacak Devir Hızı Oranı, Aktif Devir Hızı } \\
\text { Oranı, Stok Devir HızıOranı, Aktif } \\
\text { KârlılığıOranı, Özsermaye Kârlılığı Oranı, } \\
\text { Net Kâr Marjı Oranı, Brüt Kâr Marjı Oranı, } \\
\text { Pazar Değeri/Defter Değer Oranı }\end{array}$ & $\begin{array}{l}\text { BIST imalat sektöründe faaliyet gösteren } \\
\text { işletmelerin finansal performansları ve } \\
\text { pazar/defter değeri oranlarının karşılaştırıldığ } \\
\text { çalışma sonunda, işletmelerin finansal } \\
\text { performansları ile borsa performansları } \\
\text { arasında istatistik olarak anlamlı bir ilişki } \\
\text { olmadığı belirlenmiştir. }\end{array}$ \\
\hline
\end{tabular}




\begin{tabular}{|c|c|c|c|c|}
\hline (Meydan vd., 2016) & GİA & Gıda Sektörü & $\begin{array}{l}\text { Cari Oran, Asit Test Oranı, Nakit Oran, } \\
\text { Stok Bağımlılık Oranı, Aktif Devir } \\
\text { Hızıranı, Özsermaye Devir HızıOranı, } \\
\text { Alacak Devir HızıOranı, Stok Devir } \\
\text { HızıOranı, Etkinlik Oranı,Toplam } \\
\text { Borç/Toplam Aktif Oranı, Toplam } \\
\text { Borç/ÖzsermayeOranı,Duran } \\
\text { Varlık/Devamlı Sermaye Oranı, Kısa } \\
\text { Vadeli Yabancı Kaynak/Toplam } \\
\text { AktifOranı,Aktif Karlılık Oran, Özsermaye } \\
\text { Kârlılı Oranı,EkonomikRantabilite,Brüt } \\
\text { Kâr MarjıOranı Net Kâr Marjıranı, } \\
\text { Faaliyet Kâr Marjıranı, Faiz Karşıllama } \\
\text { Oranı }\end{array}$ & $\begin{array}{l}\text { GİA yöntemiyle elde edilen bulgular ile klasik } \\
\text { finansal oran analizinden elde edilen } \\
\text { sonuçları birbiriyle tutarlı olduğ } \\
\text { belirlenirken, GİA yönteminin yapın } \\
\text { değerlendirmeye bütüncül bir bakış açıs } \\
\text { kattığı tespit edilmiştir. }\end{array}$ \\
\hline $\begin{array}{c}\text { (Uygurtürk ve } \\
\text { Korkmaz, 2012) }\end{array}$ & TOPSIS & $\begin{array}{c}\text { Ana Metal Sanayi } \\
\text { Sektörü }\end{array}$ & $\begin{array}{l}\text { Cari Oran, Asit Test Oranı, Stok Devir Hızı } \\
\text { Oranı, Sabit Aktif Devir Hızı Oranı, } \\
\text { Toplam Aktif Devir Hızı Oranı, Borç- } \\
\text { Toplam Aktifler Oranı, Net Kâr Marjı } \\
\text { Oranı, Öz sermaye Kârlılı̆̆ Oranı }\end{array}$ & $\begin{array}{l}\text { 2006-2010 dönem aralı̆̆ının temel alındı̈̆ } \\
\text { çalışmada, Ana metal sanayi sektöründe } \\
\text { faaliyet gösteren firmaları finansal } \\
\text { performanslarının ylllar itibariyle değişkenlik } \\
\text { gösterdiği tespit edilmiștir. }\end{array}$ \\
\hline
\end{tabular}




\section{AMAÇ, KAPSAM VE VERILER}

Finansal performans ölçümünün amaçlandığı ilgili literatürde yer alan çalışmalar genel olarak değerlendirildiğinde, çalışmaların yürütüldüğü sektörlerin başında imalat sektörü gelirken, en sık kullanılan ÇKKV yöntemlerinin başında ise TOPSIS tekniği gelmektedir. Benzer şekilde, ulaştırma sektöründe yapılan çalışmaların birçoğunda analiz yöntemi olarak TOPSIS tekniği tercih edilmiştir. Ulusal literatürde ulaştırma sektöründe GİA yöntemi kullanılarak finansal performans ölçümünün yapıldığı bir çalışmaya ise henüz rastlanmamıştır.

Diğer yöntemlerden farklı bir teoriye sahip olan GİA yöntemi, değişkenlere sabit değerler verilmesine olanak tanımakta, fayda ve maliyet yönlü kriterlerin yanı sıra, ideal değerler alması gereken kriterler için normalizasyon aşamasında karar vericiye farklı bir alternatif sunmaktadır. GİA yöntemi, bazı finansal oranlara literatürde tanımlanan ideal değerler atanmasına olanak tanıyarak, analizin daha gerçekçi ve sağlıklı yapılmasına zemin hazırlamaktadır. İlgili literatürde kullanılan diğer yöntemlerin birçoğunda ise kriterler yalnızca maximum ve minimum yönlü olarak belirtilmekte, ideal değerler atanamamaktadır. $\mathrm{Bu}$ yönüyle GİA yönteminin finansal performans ölçümünde sağl1klı ve doğru sonuçlara erişmek adına önemli bir araç olduğu düşünülmektedir.

$\mathrm{Bu}$ doğrultuda, bu çalışmada BIST'te işlem gören ve ulaştırma sektöründe faaliyet gösteren firmaların finansal performanslarının GİA yöntemi ile ölçülmesi amaçlanmıştır. Literatürdeki çalışmaların sıklıkla TOPSIS yöntemini kullanması ve GİA yönteminin avantajlı yönleri nedeniyle, bu çalışmanın literatüre katkı yapması amaçlanmaktadır.

BIST'te işlem gören ve ulaştırma endeksi kapsamında yer alan 8 firma bulunmaktadır ve çalışma kapsamına bütün firmalar dâhil edilmiştir. 2016-2018 dönemini kapsayan 3 yıllık süreçte finansal oranları hesaplamak amacıyla gerekli olan bilgiler ise ilgili firmaların yıllık mali tablolarından elde edilmiştir.

Çalışma kapsamına alınan firmalar sıraları, BIST işlem kodları ve şirket unvanları ile birlikte Tablo 2'de yer almaktadır.

Tablo 2. Çalışma Kapsamında Yer Alan Firmalar ve Kodları

\begin{tabular}{|c|c|c|}
\hline Sira & BIST İșlem Kodu & Şirket Unvanı \\
\hline 1 & BEYAZ & BEYAZ FILO OTO KİRALAMA A.Ș. \\
\hline 2 & CLEBİ & ÇELEBİ HAVA SERVİSI A.Ș. \\
\hline 3 & DOCO & DO\&CO AKTIENGESELLSCHAFT \\
\hline 4 & GSDDE & $\begin{array}{l}\text { GSD DENIZCILİK GAYRIMMENKUL İNŞAAT SANAYİ VE TİCARET } \\
\text { A.S }\end{array}$ \\
\hline 5 & PGSUS & PEGASUS HAVA TAȘIMACILIĞI A.Ș. \\
\hline 6 & RYSAS & REYSAȘ TAȘIMACILIK VE LOJISTIKK TICARET A.Ș. \\
\hline 7 & TLMAN & TRABZON LİMAN İȘLETMECİLİĞİ A.Ş. \\
\hline 8 & THYAO & TÜRK HAVA YOLLARI A.O. \\
\hline
\end{tabular}

Likidite, mali yapı, faaliyet ve kârlılık oranları arasından 13 oran çalışma kapsamına dâhil edilmiştir. Çalışmada kullanılan finansal oranlar, işletmenin borçlarını ödeyebilme gücü, varlık ve kaynaklarının etkin kullanımı, mali yapı ve kârlılık durumu hakkında bilgi verecek oranlar arasından seçilmiştir. Çalışmada kullanılan finansal oranlar, kodları, hesaplama 
şekilleri ve uzman görüşü ve literatür taraması doğrultusunda belirlenen ideal değerleriyle birlikte Tablo 3 'te sunulmuştur.

Tablo 3. Finansal Oran Açıklamaları

\begin{tabular}{|c|c|c|c|}
\hline Sira & Kod & Finansal Oranlar ve Açıklamaları & Referans değer \\
\hline \multicolumn{4}{|c|}{ Likidite Oranları } \\
\hline 1 & $\mathrm{CO}$ & Cari Oran = Dönen Varlık / Kısa Vadeli Borçlar & 2 \\
\hline 2 & ATO & Asit Test Oranı= (Dönen Varlık-Stoklar) / Kısa Vadeli Borçlar & 1 \\
\hline 3 & NO & $\begin{array}{c}\text { Nakit Oran }=(\text { Hazır Değerler+Menkul Kıymetler }) / \text { Kısa Vadeli } \\
\text { Borçlar }\end{array}$ & 0,2 \\
\hline \multicolumn{4}{|c|}{ Mali Yapı Oranları } \\
\hline 4 & YK/ÖZK & $\begin{array}{c}\text { Yabancı Kaynakların Öz Kaynaklara Oranı = Toplam Borç/Öz } \\
\text { Sermaye Oranı }\end{array}$ & 1,00 \\
\hline 5 & YKO & Yabanc1 Kaynak Oranı = Yabanc1 Kaynaklar/Pasif Toplamı & 0,5 \\
\hline 6 & KVYK/TP & $\begin{array}{c}\text { Kısa Vadeli Yabancı Kaynak Oranı = Kısa Vadeli Borçlar/Pasif } \\
\text { Toplamı }\end{array}$ & 0,33 \\
\hline \multicolumn{4}{|c|}{$\begin{array}{l}\text { Kârlılık Oranları } \\
\end{array}$} \\
\hline 7 & $\mathrm{BKMO}$ & Brüt Kar Marjı Oranı = Brüt Satış Karı/Net Satışlar & $\max$ \\
\hline 8 & NKMO & Net Kar Marjı Oranı = Dönem Net Karı/Net Satışlar & $\max$ \\
\hline 9 & ÖKO & Öz Sermaye Karlılık Oranı = Dönem Net Karı/Öz Kaynaklar & $\max$ \\
\hline 10 & $\mathrm{AKO}$ & Aktif Karlılık Oranı = Dönem Net Karı/Aktif Toplamı & $\max$ \\
\hline \multicolumn{4}{|c|}{ Faaliyet Oranları } \\
\hline 11 & ALDHO & $\begin{array}{c}\text { Alacak Devir Hızı Oranı = Net Satışlar/Ortalama Ticari } \\
\text { Alacaklar }\end{array}$ & $\max$ \\
\hline 12 & ÖDHO & $\begin{array}{c}\text { Öz Sermaye Devir Hızı Oranı = Net Satışlar/Ortalama Öz } \\
\text { Sermaye }\end{array}$ & $\max$ \\
\hline 13 & $\mathrm{AKDHO}$ & Aktif Devir Hızı Oranı = Net Satışlar/Aktif Toplamı & $\max$ \\
\hline
\end{tabular}

Kârlılık oranları ile satışlar ve satışların maliyeti kalemleri ile kâr rakamları arasındaki ilişkiler irdelenerek, kârlılıkla ilgili yeterlilikler tespit edilmeye çalışılır ve işletme faaliyetlerinin kârlılık düzeyleri incelenir (Karğın, 2010: 40).Faaliyet göstergesi ise işletmenin sahip olduğu ve faaliyetlerini gerçekleştirmede kullandığı iktisadi kıymetlerin ne ölçüde etkin kullanıldığını tespit etmede kullanılır (Çabuk ve Lazol, 2016: 216).Faaliyet gösterilen sektör ve şirketin içinde bulunduğu duruma göre değişmekle birlikte genellikle şirket yöneticileri bu oranların en yüksek değerde olmasını arzu ederler(Uçkun ve Girginer, 2011: 56; Aydın, 2014: 92).

Bu doğrultuda, işletmenin ne ölçüde etkin yönetildiği konusunda bilgi veren kârlılık oranlarına (7-10 sırasında yer alan finansal oranlar) oranların yüksek değer almasının performans üzerinde göstereceği olumlu etkiyi ifade etmek amaciyla maksimizasyon (max) özelliğine sahip kriterler olarak atama yapılmıştır. Benzer şekilde, işletmenin sahip olduğu ve faaliyetlerini gerçekleştirmede kullandığı iktisadi kıymetlerin ne ölçüde etkin kullanıldığını gösteren faaliyet oranlarına (11-13 sirasında yer alan finansal oranlar)ise referans değeri olarak maximum değeri atanmıştır.

Diğer taraftan, işletmenin kısa vadeli borç ödeme gücünü ölçen likidite oranları ve işletmenin mali yapısı ve uzun vadeli borç ödeme gücü hakkında bilgi veren mali yapı oranları için referans değerleri belirlenirken, Tablo 4'te yer alan literatürde genel kabul görmüş oranlar kullanılmıştır. 
Tablo 4. Finansal Oranlara Ait Genel Kabul Görmüş Değerler ve Açıklamaları

\begin{tabular}{|c|c|c|}
\hline Finansal Oranlar & Genel Kabul Görmüş Değer & Kaynak \\
\hline Cari Oran & $\begin{array}{l}\text { Cari oran, işletmenin kısa vadeli borçlarını ödeme } \\
\text { gücünü gösterir. Her sektörde farklı olmakla } \\
\text { birlikte bu oranın } 2 \text { olması genellikle yeterli kabul } \\
\text { edilir. Bunun yanı sıra, sermaye piyasasının } \\
\text { yeterince gelişmediği gelişmekte olan ülkelerde } \\
\text { oranın 1,5 olmasının borç ödeme gücü açısından } \\
\text { yeterli olacağ1 ileri sürülebilir. }\end{array}$ & $\begin{array}{c}\text { Çabuk ve Lazol, } \\
\text { 2016: } 204\end{array}$ \\
\hline Asit Test Oranı & $\begin{array}{l}\text { Bu oranın } 1 \text { olması yeterli kabul edilmektedir. Söz } \\
\text { konusu rasyonun } 1 \text { olması, işletmenin kısa vadeli } \\
\text { borçlarının tamamını, para mevcudu ve hızla paraya } \\
\text { çevrilebilir kıymetlerle karşılayabileceğini gösterir. }\end{array}$ & Akgüç, 2008: 414 \\
\hline Nakit Oran & $\begin{array}{l}\text { Stoklar yanında alacakları da dönen varlıklardan } \\
\text { ayırdığı için sektörlere göre farklılık göstermekle } \\
\text { birlikte, bu oranın } 0,20 \text { olması yeterli kabul } \\
\text { edilmektedir. Oranın } 1 \text { olması, işletmenin tüm kısa } \\
\text { vadeli yabancı kaynaklarını para ve benzeri iktisadi } \\
\text { kıymetlerle ödeyebileceğini gösterir. Ancak bu } \\
\text { kadar yüksek bir oran, işletmenin elinde gereğinden } \\
\text { fazla nakit ve nakit benzeri bulundurduğunu } \\
\text { göstererek işletmenin kârlılığını olumsuz yönde } \\
\text { etkiler. }\end{array}$ & $\begin{array}{l}\text { Çabuk ve Lazol, } \\
\text { 2016: } 206\end{array}$ \\
\hline Borç/Öz sermaye Oranı & $\begin{array}{l}\text { Bu oran, işletmenin öz kaynakları ile yabancı } \\
\text { kaynakları arasındaki ilişkiyi gösterir. Oranın 1'in } \\
\text { üstünde olması, üçüncü kişilerden sağlanan fonların } \\
\text { ortaklardan sağlanan fonlardan daha fazla olduğunu } \\
\text { gösterir. Oranın 1'den küçük çıkması ise işletme } \\
\text { faaliyetlerinde kullanılan iktisadi varlıkların büyük } \\
\text { kısmının öz kaynak ile finanse edildiğini gösterir. } \\
\text { Oranın } 1 \text { olması ise öz kaynak borç dengesi } \\
\text { açısından yeterli görünür. }\end{array}$ & $\begin{array}{l}\text { Çabuk ve Lazol, } \\
\text { 2016: } 210\end{array}$ \\
\hline Yabancı Kaynak Oranı & $\begin{array}{l}\text { Bu oran, varlıkların yüzde kaçının yabancı } \\
\text { kaynaklarla finanse edildiğini gösterir. Bu oranı } \\
\text { sürekli yükselterek sınırsız bir şekilde kaldıraç } \\
\text { etkisinden yararlanma olanağı yoktur ve bu oranın } \\
\text { \%50'nin üzerine yükselmesi genellikle bir tehlike } \\
\text { işareti olarak yorumlanır. }\end{array}$ & Akgüç, 2008: 420 \\
\hline Kısa Vadeli Yabancı Kaynak Oranı & $\begin{array}{l}\text { Pasif içinde kısa vadeli yabancı kaynakların } \\
\text { ağırlığını gösteren bir orandır. Bir işletmenin çok } \\
\text { fazla kısa vadeli borcunun olması geri ödeme } \\
\text { riskini artırır. Bu oranın } 1 / 3 \text { seviyesini aşmaması } \\
\text { uygun görülür. Enflasyon dönemlerinde bu oran, } \\
\text { sermaye ve uzun vadeli yabancı kaynaklarda } \\
\text { göreceli bir statiklik nedeniyle büyüme eğilimi } \\
\text { gösterebilir. }\end{array}$ & $\begin{array}{c}\text { Çabuk ve Lazol, } \\
\text { 2016: } 211\end{array}$ \\
\hline
\end{tabular}

\section{YÖNTEM}

$\mathrm{Bu}$ çalışmada, BIST ulaştırma endeksine kayıtlı havayolu işletmelerinin finansal performanslarının ölçülmesi ve değerlendirilmesi amacıyla ilk olarak 2016-2018 dönemine ait mali tablolar kullanılarak finansal oranlar belirlenmiştir. Belirlenen finansal oranlar yardımıyla ise ÇKKV yöntemlerinden GİA aracılığıyla firmaların performans ölçümü gerçekleştirilmiştir. 
ÇKKV teknikleri, birden çok alternatif ve birbiriyle çelişen birden çok kriter olması durumunda, en iyi çözüme ulaşmak adına karar vericiye uygun bir çerçeve sunmaktadır. ÇKKV tekniklerinde problemin çözümü karar matrisinin oluşturulması ile başlamaktadır. Alternatifler, kriterler ve kriterlerin önem dereceleri ise karar matrisinin en önemli 3 elemanını oluşturmaktadır.

BIST ulaştırma endeksinde faaliyet gösteren ve Tablo 2'de yer alan 8 firma çalışmanın alternatiflerini oluştururken, firmaların yıllık mali tabloları yardımıyla elde edilen ve Tablo 3 'te yer alan13 finansal oran ise çalışmanın kriterlerini oluşturmaktadır. Her bir kriterin önem derecesini gösteren kriter ağırlıklarının atanması aşamasında 1.1nolu formül (Jahan vd., 2012:413) yardımıyla her bir kritere eşit ağılıı atanması yoluna gidilmiştir.

$$
w_{j}=\frac{1}{n}
$$

n kriter sayısını göstermektedir ve ağılıklar toplamı 1'e eşit olmalıdır.

\subsection{Gri İlişkisel Analiz (GİA)}

Gri sistem teorisi, ilk olarak Deng (1982) tarafından ortaya atılmıştır.Gri terimi, herhangi bir eksikliğin ve bilinmeyen bilginin varlığına işaret etmektedir. Gri ilişki ise, iki sistem arasındaki veya zaman içinde bir sistemde meydana gelen iki element arasındaki değişen ilişkilerin ölçümlerini ifade etmektedir. Benzerlik derecesine dayalı unsurlar arasındaki iliş̧iyi yada bu unsurlar arasındaki gelişme eğilimlerinin farklılığını ölçen analiz yöntemine ise Gri İlişkisel Analiz denilmektedir (Feng ve Wang, 2000: 136).

GİA, nicel veri setlerine uygulandığı gibi dilsel değişkenlerin kullanıldığı nitel veri setlerine de uygulanmakta, ÇKKV problemlerinde grup kararına izin veren bir yöntem olarak da uygulama alanı bulmaktadır(Yıldırım, 2018: 231).Yöntemin adımları şu şekilde özetlenebilir (Kuovd, 2008: 82-83; Wu, 2002: 211-212):

Adım 1: Karar matrisinin normalize edilmesi

Karar matrisi verileri, "daha yüksek daha iyi”, "daha düşük daha iyi” ve "nominal çözüm daha iyi" olmak üzere 3 şekilde normalize edilir. Fayda endeksli kriterler "daha yüksek daha iyi” durumunu ifade eden Eş. 1.2 yardımıyla normalize edilir.

$$
x_{i j}=\frac{y_{i j}-\operatorname{Min}\left\{y_{i j}, i=1,2, \ldots, m\right\}}{\operatorname{Max}\left\{y_{i j}, i=1,2, \ldots, m\right\}-\operatorname{Min}\left\{y_{i j}, i=1,2, \ldots, m\right\}}
$$

Maliyet endeksli kriterler ise "daha düşük daha iyi" durumunu ifade eden Eş. 1.3 yardımıla normalize edilir.

$$
x_{i j}=\frac{\operatorname{Max}\left\{y_{i j}, i=1,2, \ldots, m\right\}-y_{i j}}{\operatorname{Max}\left\{y_{i j}, i=1,2, \ldots, m\right\}-\operatorname{Min}\left\{y_{i j}, i=1,2, \ldots, m\right\}}
$$

Nominal çözüm istenen kriterler ise Eş. 1.4 kullanılarak normalize edilir. 


$$
x_{i j}=1-\frac{\left|y_{i j}-y_{j}^{*}\right|}{\operatorname{Max}\left\{y_{i j}, i=1,2, \ldots, m\right\}-y_{i j}^{*}, y_{i j}^{*}-\operatorname{Min}\left\{y_{i j}, i=1,2, \ldots, m\right\}}
$$

Adım 2: Referans serisinin oluşturulması

Referans serisi; fayda endeksli kriterler için karar matrisinde yer alan ilgili sütundaki en büyük değer; maliyet endeksli kriterler için ise en küçük değer alınarak oluşturulur.

$$
x_{0}=\left(\mathrm{x}_{01}, \mathrm{x}_{02}, \ldots, \mathrm{x}_{0 j}, \ldots, \mathrm{x}_{0 n}\right)
$$

Adım 3: Mutlak değer tablosunun Eş. 1.5 kullanılarak oluşturulur.

$$
\Delta_{0 i}(j)=\left|x_{0}^{*}(j)-x_{i}^{*}(j)\right|
$$

$$
\left[\begin{array}{cccc}
\Delta_{01}(1) & \Delta_{01}(2) & \cdots & \Delta_{01}(n) \\
\Delta_{02}(1) & \Delta_{02}(1) & \cdots & \Delta_{02}(n) \\
\Delta_{03}(1) & \cdots & & \Delta_{03}(n) \\
\vdots & \ddots & & \vdots \\
\Delta_{0 m}(1) & \Delta_{0 m}(2) & \cdots & \Delta_{0 m}(n)
\end{array}\right]
$$

Adım 4: Gri ilişki katsayıları Eş. 1.6yardımıyla hesaplanır.

$$
\begin{aligned}
& \gamma_{0 i}(j)=\frac{\Delta_{\min }+\varsigma \Delta_{\max }}{\Delta_{0 i}(j)+\varsigma \Delta_{\max }} \\
& \Delta_{\max }=\max _{i} \max _{j} \Delta_{0 i}(j) \operatorname{ve} \Delta_{\min }=\min _{i} \min _{j} \Delta_{0 i}(j)
\end{aligned}
$$

$\zeta$ ayırt edici katsayı olarak ifade edilmekte ve uygulamada genelde 0,5 değerini almaktadır (Zhai vd., 2009: 7074).

Adım 5: Gri İlişki derecesi Eş. 1.7 yardımıyla hesaplanır.

$$
\Gamma_{0 i}=\sum_{j=1}^{n}\left[w_{i}(j) \times r_{0 i}(j)\right]
$$

Alternatiflerin öncelikleri $\Gamma_{0 i}$ değerine göre sıralanır.

\section{UYGULAMA}

$\mathrm{Bu}$ çalışmanın amacı, BIST'te işlem gören ve ulaştırma sektöründe faaliyet gösteren 8 firmanın finansal performanslarını ÇKKV yöntemlerinden GİA tekniği ile değerlendirmektir. 2016-2018 dönem aralığının temel alındığı bu çalışmada, likidite, karlılık, mali yapı ve faaliyet oranları temelinde toplam 13 finansal oran belirlenmiştir. Uygulama aşamasında kriterlere eşit ağırlık verilmiş, sonrasında ise kriterlere atanan ağırlıklar kullanılarak GİA yöntemiyle firmaların belirlenen dönem aralığındaki finansal performansları değerlendirilmiştir. 


\subsection{GİA İle Performans Değerlendirmesinin Yapılması}

BIST Ulaştırma endeksinde yer alan firmaların finansal performanslarını GİA yöntemiyle değerlendirirken aşağıdaki adımlar izlenmiştir;

1. Karar matrisinin oluşturulması

2.Karar matrisi elemanlarının normalize edilmesi

3.Referans serisinin belirlenmesi

4. Mutlak değer tablosunun oluşturulması

5. Gri ilişkisel katsayı matrisinin oluşturulması

6.Gri ilişki derecesinin hesaplanması

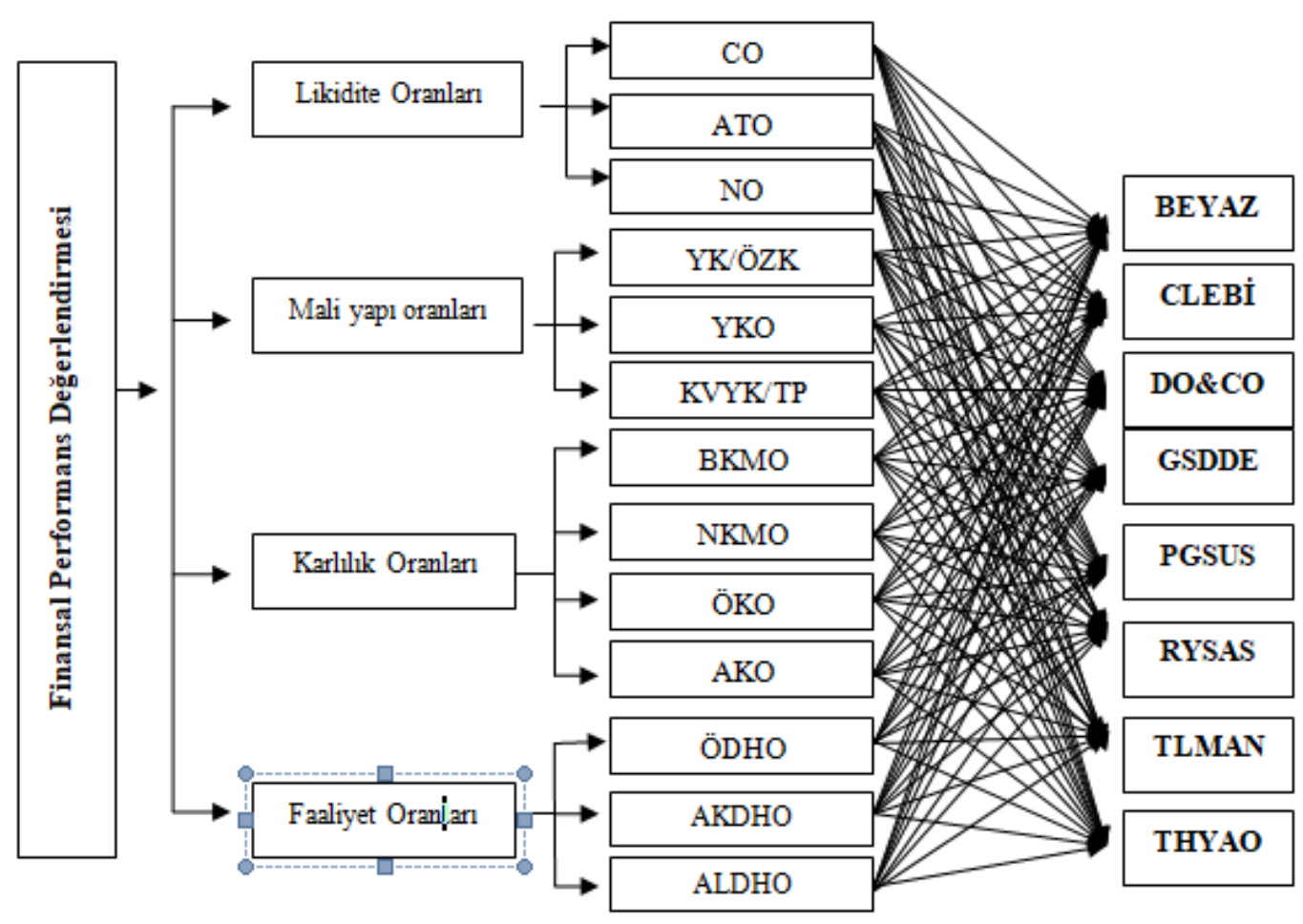

Şekil 1. Finansal Performans Değerlendirmesinin Hiyerarşik Yapısı

İlk adım karar matrisinin oluşturulmasıdır. Satırlarda alternatiflerin (8 firma) sütunlarda kriterlerin(13 finansal oran) yer aldığ1 2016-2018 dönem aralığ1 karar matrisi Tablo 5'te gösterildiği şekilde oluşturulmuştur. Örnek teşkil etmek ve oluşabilecek herhangi bir karmaşıklığın önüne geçebilmek adına ikinci adımdan itibaren yalnızca 2018 yılına ait analiz adımlarına yer verilmiştir. Son bölümde ise üç yıla ait sonuçlar bir arada sunulmuştur. 
Tablo 5. Karar Matrisi

\begin{tabular}{|c|c|c|c|c|c|c|c|c|c|c|c|c|c|c|}
\hline \multirow{3}{*}{ Alternatifler } & \multirow{3}{*}{ Yillar } & \multicolumn{13}{|c|}{ Kriterler } \\
\hline & & \multicolumn{3}{|c|}{ Likidite Oranları } & \multicolumn{3}{|c|}{ Mali Yapı Oranları } & \multicolumn{4}{|c|}{ Kârlılık Oranları } & \multicolumn{3}{|c|}{ Faaliyet Oranları } \\
\hline & & $\mathrm{CO}$ & ATO & $\mathrm{NO}$ & YK/ÖZK & YKO & KVYK/TP & BKMO & NKMO & ÖKO & $\mathrm{AKO}$ & ÖDHO & AKDHO & ALDHO \\
\hline \multirow{3}{*}{ BEYAZ } & 2016 & 1,01 & 0,69 & 0,02 & 1,12 & 0,53 & 0,50 & 10,92 & 5,09 & 28,57 & 13,46 & 5,61 & 2,64 & 13,31 \\
\hline & 2017 & 1,49 & 1,15 & 0,04 & 1,64 & 0,62 & 0,55 & 6,98 & 1,98 & 14,08 & 5,88 & 6,67 & 2,97 & 5,89 \\
\hline & 2018 & 2,32 & 2 & 0,22 & 0,59 & 0,37 & 0,34 & 4,83 & 0,15 & 0,87 & 0,41 & 5,69 & 2,71 & 10,33 \\
\hline \multirow{3}{*}{ CLEBİ } & 2016 & 0,77 & 0,73 & 0,24 & 5,82 & 0,85 & 0,40 & 23,45 & 3,78 & 30,67 & 3,89 & 7,02 & 1,03 & 7,54 \\
\hline & 2017 & 1,39 & 1,33 & 0,56 & 3,97 & 0,80 & 0,24 & 29,25 & 9,3 & 69,3 & 11,19 & 5,46 & 1,2 & 7,77 \\
\hline & 2018 & 1,18 & 1,15 & 0,45 & 3,31 & 0,77 & 0,29 & 34,26 & 15,33 & 82,64 & 17,35 & 3,78 & 1,13 & 7,62 \\
\hline \multirow{3}{*}{ DOCO } & 2016 & 1,72 & 1,59 & 0,75 & 1,47 & 0,59 & 0,31 & 1,04 & 2,3 & 16,50 & 0,05 & 1,10 & 0,36 & 9,12 \\
\hline & 2017 & 1,61 & 1,49 & 0,50 & 1,43 & 0,59 & 0,31 & 0,57 & 2,8 & 16,62 & 0,06 & 1,10 & 0,38 & 9,20 \\
\hline & 2018 & 1,66 & 1,49 & 0,45 & 1,31 & 0,57 & 0,27 & 0,59 & 3,1 & 17,60 & 0,06 & 1,08 & 0,38 & 7,54 \\
\hline \multirow{3}{*}{ GSDDE } & 2016 & 0,18 & 0,18 & 0,14 & 2,76 & 0,73 & 0,34 & $-24,34$ & $-85,72$ & $-29,42$ & $-7,83$ & 2,15 & 0,09 & 10,96 \\
\hline & 2017 & 1,01 & 0,98 & 0,83 & 3,14 & 0,76 & 0,09 & 12,12 & $-26,15$ & $-16,85$ & $-4,18$ & 0,77 & 0,16 & 19,03 \\
\hline & 2018 & 0,95 & 0,94 & 0,9 & 1,27 & 0,56 & 0,29 & 22,55 & 46,77 & 27,23 & 10,48 & 1,03 & 0,22 & 31,40 \\
\hline \multirow{3}{*}{ PGSUS } & 2016 & 1,41 & 1,38 & 0,67 & 2,58 & 0,72 & 0,18 & 5,29 & $-3,61$ & $-8,49$ & $-2,38$ & 2,36 & 0,66 & 17,49 \\
\hline & 2017 & 1,66 & 1,65 & 1,07 & 2,25 & 0,69 & 0,23 & 14,49 & 9,39 & 24,61 & 7,33 & 2,15 & 0,78 & 28,60 \\
\hline & 2018 & 1,24 & 1,22 & 0,77 & 2,68 & 0,73 & 0,26 & 15,23 & 6,12 & 16,21 & 4,66 & 2,23 & 0,76 & 35,30 \\
\hline \multirow{3}{*}{ RYSAS } & 2016 & 0,83 & 0,82 & 0,27 & 4,78 & 0,83 & 0,24 & 22,04 & $-8,81$ & $-26,71$ & $-3,01$ & 1,97 & 0,34 & 3,83 \\
\hline & 2017 & 0,6 & 0,59 & 0,33 & 6,66 & 0,87 & 0,34 & 23,86 & $-3,38$ & $-12,49$ & $-1,26$ & 2,64 & 0,37 & 10,69 \\
\hline & 2018 & 0,44 & 0,43 & 0,18 & 22,72 & 0,96 & 0,39 & 28,19 & $-13,39$ & $-88,55$ & $-5,41$ & 9,33 & 0,4 & 8,59 \\
\hline \multirow{3}{*}{ TLMAN } & 2016 & 0,87 & 0,87 & 0,02 & 0,92 & 0,48 & 0,31 & 56,31 & 39,90 & 0,38 & 0,20 & 0,95 & 0,50 & 33,35 \\
\hline & 2017 & 2,14 & 2,13 & 0,002 & 1,04 & 0,51 & 0,29 & 61,61 & 43,46 & 0,48 & 0,24 & 1,11 & 0,55 & 35,48 \\
\hline & 2018 & 2,55 & 2,54 & 0,002 & 0,62 & 0,38 & 0,25 & 61,13 & 46,32 & 0,50 & 0,30 & 1,09 & 0,64 & 20,5 \\
\hline \multirow{3}{*}{ THYAO } & 2016 & 0,8 & 0,75 & 0,33 & 2,61 & 0,72 & 0,24 & 11,6 & $-0,16$ & $-0,01$ & $-0,07$ & $-0,26$ & 0,45 & 22,09 \\
\hline & 2017 & 0,85 & 0,8 & 0,44 & 2,40 & 0,71 & 0,24 & 19,7 & 1,61 & 0,03 & 0,96 & 3,36 & 0,59 & 19,5 \\
\hline & 2018 & 0,87 & 0,83 & 0,32 & 2,49 & 0,71 & 0,25 & 21,59 & 6,44 & 0,13 & 4,55 & 15,72 & 0,71 & 20,67 \\
\hline
\end{tabular}


Tablo 5'te yer alan veriler dikkate alınarak firmalar bazında genel bir değerlendirme yapıldığında, likidite göstergesi kapsamında yer alan $\mathrm{CO}$ ve ATO bakımından TLMAN, DOCO, BEYAZ, PGSUS ve CLEBİ firmaları en yüksek değerleri almışlardır. THYAO, GSDDE ve RYSAS firmalarına ait değerler ise belirlenen ideal değerlerin oldukça altında kalmıştır. NO ise genel olarak belirlenen standardın üzerinde gerçekleşmiştir. Mali yapı oranları açısından bakıldığında, TLMAN dışındaki diğer firmaların YKO ve YK/ÖZK oranları belirlenen ideal değerin üstünde seyretmiştir. KVYK/TP oranına göre ise genel olarak bütün firmaların iyi bir durumda olduğu söylenebilir. Kârlılık oranları incelendiğinde, BKMO ve NKMO açısından TLMAN; ÖKO ve AKO açısından ise CLEBİ firmaları yüksek değerler alarak diğer firmalara kıyasla yeterli düzeyde bir kârlılık elde etmişlerdir. GSDDE ve RYSAS ise NKMO, ÖKO ve AKO bakımından oldukça düşük bir değer almıştır. Faaliyet oranları incelendiğinde ise ÖDHO'ya göre THYAO, AKDHO'ya göre BEYAZ, ALDHO'ya göre ise TLMAN firmalarının diğer firmalara kıyasla daha iyi bir pozisyonda olduğu söylenebilir.

Yapılan değerlendirmeden sonra analizin ikinci adımı, karar matrisi verilerinin normalize edilmesi sürecini kapsamaktadır. Normalizasyon işlemi, farklı ölçü birimi ve büyüklüklere sahip olan verilerin benzer standartlara sahip olması için yapılmaktadır. $\mathrm{Bu}$ aşamada, yüksek değer alması firmanın geleceği açısından olumlu görülen oranlar için "daha yüksek daha iyi” şeklinde ifade edilen normalizasyon formülü kullanılırken, ideal değerde olması istenen finansal oranlar için ise "nominal çözüm daha iyi" şeklinde ifade edilebilen formülden yararlanılmıştır. Bu doğrultuda, kârlılık ve faaliyet oranları kapsamında yer alan 7 finansal oranın (7-13sırasında yer alan finansal oranlar) normalizasyon aşamasında 1.2numaralıeşitlikten faydalanılmıştır. Likidite ve mali yapı oranları kapsamında yer alan 6 oranın (1-6 sırasında yer alan finansal oranlar) normalize aşamasında ise (1.4) numaralı eşitlikten faydalanılmıştır. Oluşturulan normalize edilmiş karar matrisi Tablo 6'da sunulmuştur.

Tablo 6. Normalize Karar Matrisi

\begin{tabular}{|c|c|c|c|c|c|c|c|c|c|c|c|c|c|}
\hline & \multicolumn{3}{|c|}{ Likidite Oranları } & \multicolumn{3}{|c|}{ Mali Yapı Oranları } & \multicolumn{4}{c|}{ Kârlılı Oranları } & \multicolumn{3}{c|}{ Faaliyet Oranları } \\
\hline BEYAZ & 0,795 & 0,351 & 0,971 & 0,981 & 0,717 & 0,875 & 0,070 & 0,225 & 0,522 & 0,256 & 0,317 & 1 & 0,101 \\
\hline CLEBİ & 0,474 & 0,903 & 0,643 & 0,894 & 0,413 & 0,5 & 0,556 & 0,477 & 1 & 1 & 0,187 & 0,365 & 0,003 \\
\hline DOCO & 0,782 & 0,682 & 0,643 & 0,986 & 0,848 & 0,25 & 0 & 0,274 & 0,620 & 0,240 & 0,003 & 0,064 & 0 \\
\hline GSDDE & 0,327 & 0,961 & 0 & 0,988 & 0,870 & 0,5 & 0,363 & 1 & 0,676 & 0,698 & 0 & 0 & 0,860 \\
\hline PGSUS & 0,513 & 0,857 & 0,186 & 0,923 & 0,5 & 0,125 & 0,242 & 0,324 & 0,612 & 0,442 & 0,082 & 0,217 & 1 \\
\hline RYSAS & 0 & 0,630 & 0,971 & 0 & 0 & 0,25 & 0,456 & 0 & 0 & 0 & 0,565 & 0,072 & 0,038 \\
\hline TLMAN & 0,647 & 0 & 0,717 & 0,983 & 0,739 & 0 & 1 & 0,993 & 0,520 & 0,251 & 0,004 & 0,169 & 0,467 \\
\hline THYAO & 0,276 & 0,890 & 0,829 & 0,931 & 0,543 & 0 & 0,347 & 0,330 & 0,518 & 0,438 & 1 & 0,197 & 0,473 \\
\hline $\begin{array}{c}\text { Referans } \\
\text { Serisi }\end{array}$ & 0,795 & 0,961 & 0,971 & 0,988 & 0,870 & 0,875 & 1 & 1 & 1 & 1 & 1 & 1 & 1 \\
\hline
\end{tabular}

Üçüncü adımda, normalize karar matrisi elemanları içinden en yüksek değer alınarak her bir alternatif için referans serisi oluşturulur. Elde edilen referans serisi Tablo 6'da sunulmuştur. 
Dördüncü adımda, (1.5) numaralı eşitlik yardımıyla mutlak değerler tablosu oluşturulur. Referans değerlerinden normalize edilmiş değerler çıkarılarak elde edilen mutlak değer tablosu Tablo 7'de sunulmuştur.

Tablo 7. Mutlak Değer Tablosu

\begin{tabular}{|c|c|c|c|c|c|c|c|c|c|c|c|c|c|}
\hline & \multicolumn{3}{|c|}{ Likidite Oranları } & \multicolumn{4}{c|}{ Mali Yapı Oranları } & \multicolumn{4}{c|}{ Kârlık Oranları } & \multicolumn{3}{c|}{ Faaliyet Oranları } \\
\hline BEYAZ & 0 & 0,610 & 0 & 0,006 & 0,152 & 0 & 0,930 & 0,775 & 0,478 & 0,744 & 0,683 & 0 & 0,899 \\
\hline CLEBİ & 0,321 & 0,058 & 0,329 & 0,094 & 0,457 & 0,375 & 0,444 & 0,523 & 0 & 0 & 0,813 & 0,635 & 0,997 \\
\hline DOCO & 0,013 & 0,279 & 0,329 & 0,002 & 0,022 & 0,625 & 1 & 0,726 & 0,380 & 0,760 & 0,997 & 0,936 & 1 \\
\hline GSDDE & 0,468 & 0 & 0,971 & 0 & 0 & 0,375 & 0,637 & 0 & 0,324 & 0,302 & 1 & 1 & 0,140 \\
\hline PGSUS & 0,282 & 0,104 & 0,786 & 0,065 & 0,370 & 0,75 & 0,758 & 0,676 & 0,388 & 0,558 & 0,918 & 0,783 & 0 \\
\hline RYSAS & 0,795 & 0,331 & 0 & 0,988 & 0,870 & 0,625 & 0,544 & 1 & 1 & 1 & 0,435 & 0,928 & 0,962 \\
\hline TLMAN & 0,147 & 0,961 & 0,254 & 0,005 & 0,130 & 0,875 & 0 & 0,007 & 0,480 & 0,749 & 0,996 & 0,831 & 0,533 \\
\hline THYAO & 0,519 & 0,071 & 0,143 & 0,056 & 0,326 & 0,875 & 0,653 & 0,670 & 0,482 & 0,562 & 0 & 0,803 & 0,527 \\
\hline
\end{tabular}

Beşinci adımda,tüm finansal oranların gri ilişkisel katsayıya dönüştürülmesi amacıyla $\zeta=0,5$ alınarak 1.6 numaralı eşitlik kullanılarak gri ilişkisel katsayı matrisi oluşturulmuştur. Elde edilen sonuçlar Tablo 8'de sunulmuştur.

Tablo 8.Gri İlişkisel Katsayı Matrisi Tablosu

\begin{tabular}{|c|c|c|c|c|c|c|c|c|c|c|c|c|c|}
\hline & \multicolumn{3}{|c|}{ Likidite Oranları } & \multicolumn{4}{c|}{ Mali Yapı Oranları } & \multicolumn{4}{c|}{ Kârlılı Oranları } & \multicolumn{3}{c|}{ Faaliyet Oranları } \\
\hline BEYAZ & 1 & 0,440 & 1 & 0,987 & 0,741 & 1 & 0,350 & 0,392 & 0,511 & 0,402 & 0,423 & 1 & 0,357 \\
\hline CLEBI & 0,554 & 0,892 & 0,596 & 0,840 & 0,488 & 0,538 & 0,530 & 0,489 & 1 & 1 & 0,381 & 0,441 & 0,334 \\
\hline DOCO & 0,969 & 0,632 & 0,596 & 0,996 & 0,952 & 0,412 & 0,333 & 0,408 & 0,568 & 0,397 & 0,334 & 0,348 & 0,333 \\
\hline GSDDE & 0,459 & 1 & 0,333 & 1 & 1 & 0,538 & 0,440 & 1 & 0,607 & 0,624 & 0,333 & 0,333 & 0,781 \\
\hline PGSUS & 0,585 & 0,822 & 0,382 & 0,884 & 0,541 & 0,368 & 0,397 & 0,425 & 0,563 & 0,473 & 0,353 & 0,390 & 1 \\
\hline RYSAS & 0,333 & 0,592 & 1 & 0,333 & 0,333 & 0,412 & 0,479 & 0,333 & 0,333 & 0,333 & 0,535 & 0,350 & 0,342 \\
\hline TLMAN & 0,729 & 0,333 & 0,656 & 0,990 & 0,769 & 0,333 & 1 & 0,985 & 0,510 & 0,400 & 0,334 & 0,376 & 0,484 \\
\hline THYAO & 0,434 & 0,871 & 0,773 & 0,898 & 0,571 & 0,333 & 0,434 & 0,427 & 0,509 & 0,471 & 1 & 0,384 & 0,487 \\
\hline
\end{tabular}

Tablo 8'de yer alan bilgilere göre, DOCO dışındaki diğer firmalar bazı finansal oranlar bakımından tam etkinliğe $(1,00)$ ulaşmıştır. Buna göre; BEYAZ firması cari oran, nakit oran, kısa vadeli yabancı kaynak oranı, aktif devir hızı oranı bakımından; CLEBİ firması öz sermaye kârlılık oranı ve aktif kârlılık oranı bakımından; GSDDE firması asit test oranı, yabancı kaynakların öz kaynaklara oranı, yabancı kaynak oranı ve net kâr marjı oranı bakımından; PGASUS firması aktif devir hızı oranı bakımından; RYSAS firması nakit oran bakımından; TLMAN firması brüt kâr marjı oranı bakımından ve THYAO firması ise alacak devir hızı oranı bakımından tam etkinliğe ulaşmıştır.

Son adımda ise çalışma kapsamında yer alan firmaların gri ilişsisel dereceleri hesaplanmıştır. Gri ilişkisel derecelerin hesaplanmasında (1.7) numaralı formülden yararlanılmıştır. Elde edilen sonuçlar Tablo 9'da sunulmuştur. 
Tablo 9. Gri İlişkisel Dereceleri

\begin{tabular}{|c|c|c|c|c|c|c|c|c|c|c|c|c|c|}
\hline & \multicolumn{3}{|c|}{ Likidite Oranları } & \multicolumn{3}{|c|}{ Mali Yapı Oranları } & \multicolumn{4}{c|}{ Kârlılık Oranları } & \multicolumn{3}{c|}{ Faaliyet Oranları } \\
\hline BEYAZ & 0,077 & 0,034 & 0,077 & 0,076 & 0,057 & 0,077 & 0,027 & 0,030 & 0,039 & 0,031 & 0,033 & 0,077 & 0,027 \\
\hline CLEBI & 0,043 & 0,069 & 0,046 & 0,065 & 0,038 & 0,041 & 0,041 & 0,038 & 0,077 & 0,077 & 0,029 & 0,034 & 0,026 \\
\hline DOCO & 0,075 & 0,049 & 0,046 & 0,077 & 0,073 & 0,032 & 0,026 & 0,031 & 0,044 & 0,031 & 0,026 & 0,027 & 0,026 \\
\hline GSDDE & 0,035 & 0,077 & 0,026 & 0,077 & 0,077 & 0,041 & 0,034 & 0,077 & 0,047 & 0,048 & 0,026 & 0,026 & 0,060 \\
\hline PGSUS & 0,045 & 0,063 & 0,029 & 0,068 & 0,042 & 0,028 & 0,031 & 0,033 & 0,043 & 0,036 & 0,027 & 0,030 & 0,077 \\
\hline RYSAS & 0,026 & 0,046 & 0,077 & 0,026 & 0,026 & 0,032 & 0,037 & 0,026 & 0,026 & 0,026 & 0,041 & 0,027 & 0,026 \\
\hline TLMAN & 0,056 & 0,026 & 0,050 & 0,076 & 0,059 & 0,026 & 0,077 & 0,076 & 0,039 & 0,031 & 0,026 & 0,029 & 0,037 \\
\hline THYAO & 0,033 & 0,067 & 0,059 & 0,069 & 0,044 & 0,026 & 0,033 & 0,033 & 0,039 & 0,036 & 0,077 & 0,030 & 0,037 \\
\hline
\end{tabular}

Tablo 9'da yer alan her bir alternatife ait Gri İlişkisel Dereceleri toplanarak performans skorları elde edilmiş ve nihai sıralama yapılmıştır. Elde edilen sonuçlar Tablo 10'da sunulmuştur.

Tablo 10. Gri İlişkisel Analiz Sonuçları

\begin{tabular}{|c|c|c|c|c|c|c|}
\hline & $\mathbf{2 0 1 6}$ & Siralama & $\mathbf{2 0 1 7}$ & Siralama & $\mathbf{2 0 1 8}$ & Siralama \\
\hline BEYAZ & 0,714 & 2 & 0,641 & 2 & 0,662 & 1 \\
\hline CLEBI & 0,609 & 3 & 0,598 & 3 & 0,622 & 3 \\
\hline DOCO & 0,577 & 4 & 0,549 & 4 & 0,560 & 6 \\
\hline GSDDE & 0,470 & 8 & 0,438 & 8 & 0,650 & 2 \\
\hline PGSUS & 0,483 & 7 & 0,526 & 5 & 0,553 & 7 \\
\hline RYSAS & 0,494 & 6 & 0,487 & 7 & 0,439 & 8 \\
\hline TLMAN & 0,746 & 1 & 0,729 & 1 & 0,608 & 4 \\
\hline THYAO & 0,522 & 5 & 0,512 & 6 & 0,584 & 5 \\
\hline
\end{tabular}

Çalışma sonunda elde edilen ve Tablo 10'da yer alan bilgiler, yorumlamayı kolaylaştırmak adına Şekil 2'de sunulmuştur.

Grafik 1. Yıllara Göre Performans Sıralamaları

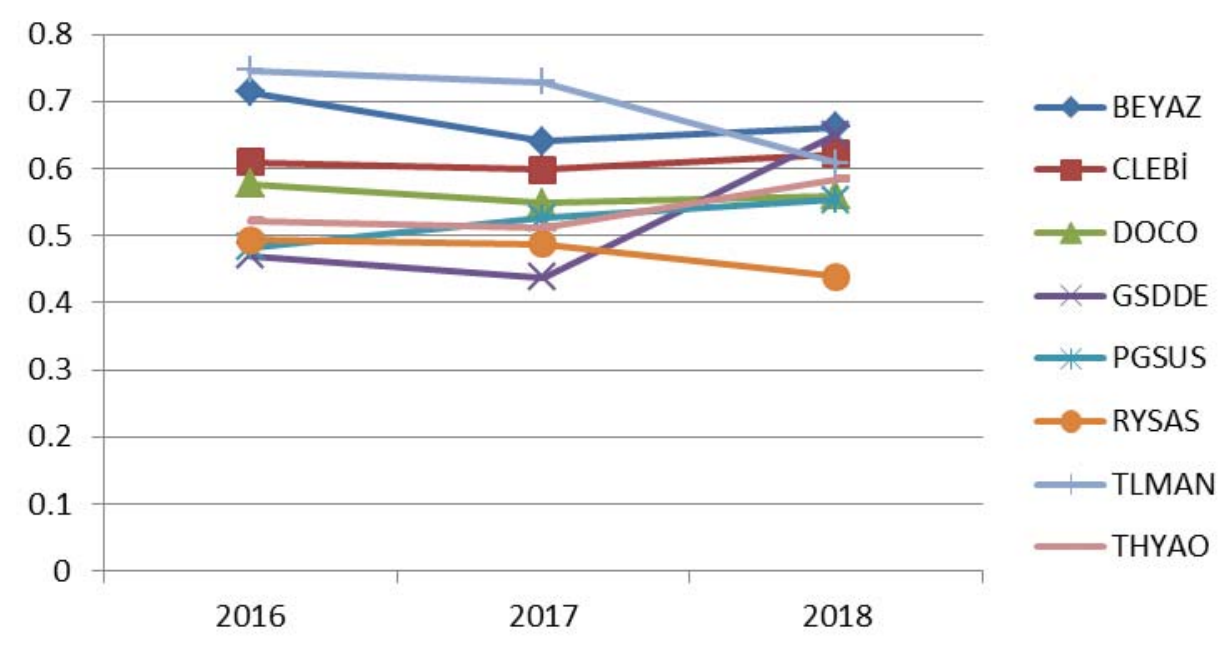


Değerlendirme sonuçlarına göre, 2016 ve 2017 yılında en iyi performans gösteren ilk 3 firma TLMAN, BEYAZ ve CLEBİ olurken, 2018 yllında en iyi performans gösteren ilk 3 firma ise BEYAZ, GSDDE ve CLEBİ olmuştur. 2016 ve 2017 yllında en düşük performansa sahip olan firma GSDDE olurken, 2018 yilında en düşük performansa sahip olan firma RYSAS olmuştur.

\section{SONUÇ VE ÖNERILER}

$\mathrm{Bu}$ çalışmada, işletmelerin bilanço ve gelir tablolarından elde edilen finansal oranlar yardımıyla finansal performansları incelenmiş ve analiz yöntemi olarak son yıllarda sıklıkla kullanılan ÇKKV yöntemlerinden GİA yöntemi kullanılmıştır. 2016-2018 döneminin analiz kapsamına dâhil edildiği çalışmada, BIST ulaştırma endeksinde yer alan 8 firma çalışmanın örneklemini oluşturmuştur. GİA değerleri likidite, mali yapı, kârlıık ve faaliyet oranları kapsamında yer alan 13 temel orana göre belirlenmiştir.

Çalışmaya ilişkin uygulama sonuçlarına göre, firmalara ait GİA değerleri çok yüksek sapmalar göstermezken, performans sıralamaları yıllar bazında genel olarak farklılaşmıştır. TLMAN firması 2016 ve 2017 yillarında finansal performans bakımından ilk sirada yer alırken, 2018 yılında dördüncü sırayı almıştır. BEYAZ firması 2016 ve 2017 yılı sıralama sonucuna göre ikinci sırada yer alırken, 2018 yılı sıralamasında ilk sırada yer almıştır. Farklı sıralarda yer almakla birlikte benzer durum DOCO, GSDDE, PGSUS ve THYAO için de geçerlidir. Buna karşın, CLEBİ firmasının her üç yıla ait sıralama sonucuna göre yeri değişmemiş ve üçüncü sırada yer almıştır. Ayrıca, Tablo 10'da yer alan bilgilerden hareketle firmaların genel ortalaması hesaplandığında en başarılı şirket TLMAN, en başarısız şirket ise RYSAS olmuştur. Yüksek kârlllığa sahip işletmelerin GİA ile elde edilen sıralamada ön sıralarda yer aldıkları tespit edilmiştir.

Gelecekte yapılması düşünülen çalışmalarda, ENTROPY, CRITIC ve Standart Sapma Yöntemi gibi objektif yöntemler ile ya da AHP ve Delphi gibi sübjektif yöntemler ile kriterlere farklı ağırlıklar atanabilir ve kriter ağılıklarının çalışma sonuçları üzerindeki etkisi incelenebilir. Ayrıca, farklı ÇKKV yöntemleri ve farklı finansal oranlar kullanılarak alternatif ve kriter sayısı artırılabilir ve elde edilen sonuçlar karşılaş̧ırılabilir.

\section{KAYNAKLAR}

AKBULUT, Ramazan - RENÇBER, Ömer Faruk (2015), "BIST'te İmalat Sektöründeki İşletmelerin Finansal Performansları Üzerine Bir Araştırma", Muhasebe ve Finansman Dergisi, (65), ss.117-136.

AKGÜÇ, Öztin (2008), Mali Tablolar Analizi, Genişletilmiş ve Gözden Geçirilmiş 13. Bask1, Avciol Basım Yayın, İstanbul.

AKGÜN, Melek - SOY TEMÜR, Ayşe (2016), "BIST Ulaştırma Endeksine Kayıtlı Şirketlerin Finansal Performanslarının TOPSIS Yöntemi ile Değerlendirilmesi”, Uluslararası Yönetim İktisat ve İşletme Dergisi, (30), ss.173-186.

ATMACA, Metin (2012), “IMKB'de İşlem Gören Spor Şirketlerinin TOPSIS Yönetimi ile Finansal Performans Değerlendirmesi”, İktisat İşletme ve Finans, 27(320), ss.91-108. 
AYDIN, Nurhan (2014), "Finansal Analiz", Finansal Yönetim ( Editörler: Güven Sevil ve Mehmet Başar, Anadolu Üniversitesi Yayınları, Eskişehir, ss.84-113.

BALEŽENTIS, Alvydas - BALEŽENTIS, Tomas - MISIUUNAS, Algimantas (2012), “An Integrated Assessment of Lithuanian Economic Sectors Based on Financial Ratiosand Fuzzy MCDM Methods", Technological and Economic Development of Economy, 18(1), pp.34-53.

BO, Jin - HAIDONG, L1 (2008), "Research On Financial Early Warningfor Listed Companies Basedon TOPSIS Method", Inthe 5th International Annual Conference on WTO and Financial Engineering, January, pp. 589-595.

ÇABUK, Adem - LAZOL, İbrahim (2016), Mali Tablolar Analizi, 15. Bask1, Ekin Kitabevi, Bursa.

DENG, JuLong (1982), "Control ProblemsofGreySystems", Systemsand Control Letters, $1(5)$, pp.288-294.

DUMANOĞLU, Sezai - ERGÜL, Nuray (2010), “IMKB'de İşlem Gören Teknoloji Şirketlerinin Mali Performans Ölçümü’, Muhasebe ve Finansman Dergisi, (48), ss.101-111.

ERDOĞAN, H. Tuba (2016), "Ulaşım Hizmetlerinin Ekonomik Kalkınma Üzerine Etkisi”, İstanbul Gelişim Üniversitesi Sosyal Bilimler Dergisi, 3(1), ss.187-215.

ERTUĞRUL, İrfan - KARAKAŞOĞLU, Nilsen (2009). Performance Evaluation of Turkish Cement FirmsWith Fuzzy Analytic Hierarchy Processand TOPSIS Methods", Expert Systems with Applications, 36(1), pp.702-715.

ESBOUEİ, SaberKhalili - GHADIKOLAEİ, AbdolhamidSafaei - ANTUCHEVİCIENE, Jurgita (2014), "Using FANP andFuzzyVIKORforRankingManufacturingCompaniesBasedonTheirFinancialPerform ance", EconomicComputation\&EconomicCyberneticsStudies\&Research, 48(3), pp.141-162.

FARROKH, Mojtaba - HEYDARI, Hossein - JANANI, Hamid (2016), "Two Comparative MCDM Approaches For EvaluatingThe Financial Performance of IranianBasic Metals Companies". Iranian Journal of Management Studies, 9(2), pp.359-382.

FENG, ChengMin - WANG, RongTsu (2000), "PerformanceEvaluationforAirlinesIncluding the Consideration of Financial Ratios", Journal Of Air Transport Management, 6(3), pp.133-142.

GERÇEK, Haluk (2001), "Otoyolların Mali ve Ekonomik Değerlendirilmesi”. 5. Ulaştırma Kongresi, TMMOB, İstanbul, ss.89-100.

GÜMÜŞ, Umut Tolga - ÇIBIK, Erkan (2019), "BIST'de İşlem Gören Ulaştırma Sektöründeki Firmaların Finansal Performans Analizleri: MOORA ve VIKOR Uygulama", Turan-Sam, 11(41), ss.275-284. 
JAHAN, Ali - MUSTAPHA, Faizal - SAPUAN, S. M - ISMAIIL, Md YusofBAHRAMINASAB, Marjan (2012), "A Framework for Weighting of Criteriain Ranking Stage of Material Selection Process", The International Journalof Advanced Manufacturing Technology, 58(1), pp.411-420.

KARĞIN, Mahmut (2010), Muhasebe Verileri Olarak Finansal Oranlar ve İstatistiksel Özellikleri, Gazi Kitabevi, Ankara.

KENDIRLİ, Selçuk - KAYA, Aslıhan (2016), "BIST-Ulaştırma Endeksinde Yer Alan Firmaların Mali Performanslarının Ölçülmesi ve TOPSIS Yönteminin Uygulanması", Manas Sosyal Araştırmalar Dergisi, 5(1), ss.34-63.

KUO, Yiyo - YANG, Taho - HUANG, GuanWei (2008), "TheUseofGreyRelationalAnalysisinSolvingMultipleAttributeDecisionMakingProble ms", Computers\&IndustrialEngineering, 55(1), pp.80-93.

MEYDAN, Cebrail - YILDIRIM, Bahadır Fatih - SENGER, Ötüken (2016), “BIST’te İșlem Gören Gıda İşletmelerinin Finansal Performanslarının Gri İlişkisel Analiz Yöntemi Kullanılarak Değerlendirilmesi”, Muhasebe ve Finansman Dergisi, (69), ss.147-165.

MOGHIMI, Rohollah - ANVARI, Alireza (2014), “An İntegratedFuzzyMCDMApproachandAnalysistoEvaluatetheFinancialPerformanceof IranianCementCompanies", The International Journalof Advanced ManufacturingTechnology, 71(1-4), pp.685-698.

ÖMÜRBEK, Vesile - KINAY, Bülent (2013), "Havayolu Taşımacıllı̆ı̆ Sektöründe TOPSIS Yöntemiyle Finansal Performans Değerlendirmesi”. Süleyman Demirel Üniversitesi İktisadi ve İdari Bilimler Fakültesi Dergisi, 18(3), ss.343-363.

ÖZDAĞOĞLU, Aşkın - GÜMÜŞ, Yusuf - ÖZDAĞOĞLU, Güzin - GÜMÜŞ, Gülüzar Kurt (2017), "Evaluating Financial PerformancewithGreyRelationalAnalysis: An Application of ManufacturingCompaniesListedon Borsa İstanbul", Journal Of Accounting \& Finance, (73), pp.289-312.

REZAİ, Kamran - RAMIYANI, Sara Saeidi - NAZARİ-SHIRKOUHI, Salman BADIZZADEH, Ali (2014), "EvaluatingPerformanceofIranianCementFirmsUsing an IntegratedFuzzyAHP-VIKORMethod", Applied Mathematical Modelling, 38(21-22), pp.5033-5046.

SHAVERDİ, Meysam - HESHMATİ, MohammadRasoul - RAMEZANI, Iman (2014), "Application of Fuzzy AHP Approach for Financial Performance Evaluation of Iranian Petrochemical Sector”, Procedia Computer Science, (31), pp.995-1004.

TAYYAR, Nezih - AKCANLİ, Fatma- GENÇ, Erhan - EREM, Iş11 (2014), "BIST'e Kayıtlı Bilişim ve Teknoloji Alanında Faaliyet Gösteren İşletmelerin Finansal Performanslarının Analitik Hiyerarşi Prosesi (AHP) ve Gri İlişkisel Analiz (GİA) Yöntemiyle Değerlendirilmesi”, Muhasebe ve Finansman Dergisi, (61), ss.19-40 
UYGURTÜRK, Hasan - KORKMAZ, Turhan (2012), "Finansal Performansın TOPSIS Çok Kriterli Karar Verme Yöntemi ile Belirlenmesi: Ana Metal Sanayi İşletmeleri Üzerine Bir Uygulama", Eskişehir Osmangazi Üniversitesi İktisadi ve İdari Bilimler Dergisi, 7(2), ss.95-115

WANG, TienChin - CHANG, JuiFang - ANH, TruongNgoc - CHANG, WanTseng(2010), "Applying TOPSIS Method to Evaluate the Business Operation Performance of Vietnam Listing Securities Companies", 2010 International Conference On Computational Aspects of Social Networks, IEEE, pp. 273-277.

WANG, YuJie (2008), “Applying FMCDMto Evaluate Financial Performance of Domestic Airlinesin Taiwan”, Expert Systems with Applications, 34(3), pp.1837-1845.

WU, HsinHung (2002), "A Comparative Study of Using Grey Relational Analysis in Multiple Attribute Decision Making Problems” Quality Engineering, 15(2), pp.209-217.

YALCIN, Nese - BAYRAKDAROGLU, Ali - KAHRAMAN, Cengiz (2012), “Application of FuzzyMulti-Criteria Decision Making Methods for Financial Performance Evaluation of Turkish Manufacturing Industries", Expert Systems with Applications, 39(1), pp.350-364.

YILDIRIM, Bahadır Fatih - ÖNDER, Emrah (2018), Çok Kriterli Karar Verme Yöntemleri, 3. Bask1, Dora Yayıncılık, Bursa.

ZHAİ, LianYin - KHOO, LiPheng - ZHONG, ZhaoWei (2009), "Design Concept Evaluation in Product Development Using Rough Setsand Grey Relational Analysis", Expert Systems with Applications, (36), pp.7072-7079. 
